\title{
New records of Agaricaceae (Basidiomycota, Agaricales) from Araripe National Forest, Ceará State, Brazil
}

\section{Nascimento $\mathrm{CC}^{1}$ and Alves $\mathrm{MH}^{1}$}

\author{
${ }^{1}$ Universidade Federal do Piauí, Campus Parnaíba. Avenida São Sebastião, 2819. CEP 64202-020. Parnaíba, PI, \\ Brazil
}

Nascimento CC, Alves MH 2014 - New records of Agaricaceae (Basidiomycota, Agaricales) from Araripe Nacional Forest, Ceará State, Brazil. Mycosphere 5(2), 319-332, Doi 10.5943/mycosphere/5/2/6

\begin{abstract}
An account is given of some new records of Agaricaceae species collected in fragments of the Araripe National Forest in the following municipalities of Ceará state: Barbalha, Crato and Santana do Cariri. As preliminary results, a total of six species belonging to five genera have been identified: Agaricus stijvei, Chlorophyllum hortense, Cystolepiota seminuda and Lepiota plumbicolor are new records from the Northeast of Brazil, while Leucocoprinus birnbaumii and Leucocoprinus fragilissimus are new records from the state of Ceará. Complete morphological descriptions, notes, drawings and color pictures of the basidiomes are provided.
\end{abstract}

Key words - Basidiomycetes - mushrooms - Northeast Brazil - taxonomy

\section{Introduction}

Agaricaceae Chevall. is a well-known family of Agaricales (Euagaric clade sensu Hibbett et al., 1997 and Hibbett \& Thorn, 2001) with global distribution. It is a monophyletic group of saprotrophic fungi that exhibits huge diversity in spore colour, and in structure of the pileus covering (Vellinga 2004). That family is of great scientific interest, comprising symbionts, edible, poisonous and medicinal species, most of them involved in biotechnological processes (Singer 1986, Alexopoulos et al. 1996, Didukh et al. 2003).

According to Kirk et al. (2008), the family comprises 85 genera and 1.340 species, including agaricoid (Singer 1986, Redhead et al. 2001), secotioid and gasteroid taxa (Krüger et al. 2001, Moncalvo et al. 2002). Morphologically, the agaricoid species of Agaricaceae can be recognized by the following combination of characters: Basidiome pluteoid, lepiotoid or tricholomatoid, rarely collybioid or mycenoid; lamellae free or rarely adnexed; veil commonly forming a annulus and/or characteristic squamules on the pileal and stipe surfaces; basidiospores hyaline to pigmented, end hymenoforal trama regular to subregular (Pegler 1986, Vellinga 2004).

In the last few decades, the progress of recording and describing Agaricaceae species in Brazil is evident, especially in south and southeastern Brazil. However, many areas of the country with a fantastic biodiversity remain unexplored and their mycota unknown. To date, few comprehensive studies have been undertaken to the knowledge of the diversity of this group in Brazil; for a list of works that record Agaricaceae taxa from Brazil see Wartchow et al. (2008). Specifically for the Brazilian Northeast, the family have been reported in few fragmented studies, for example: Batista (1957); Kimbrough et al. (1994); Maia (1998); Maia et al. (2002), Wartchow et al. (2008), all from Pernambuco state and recently Alves et al. (2012) from Piauí state. Therefore, 

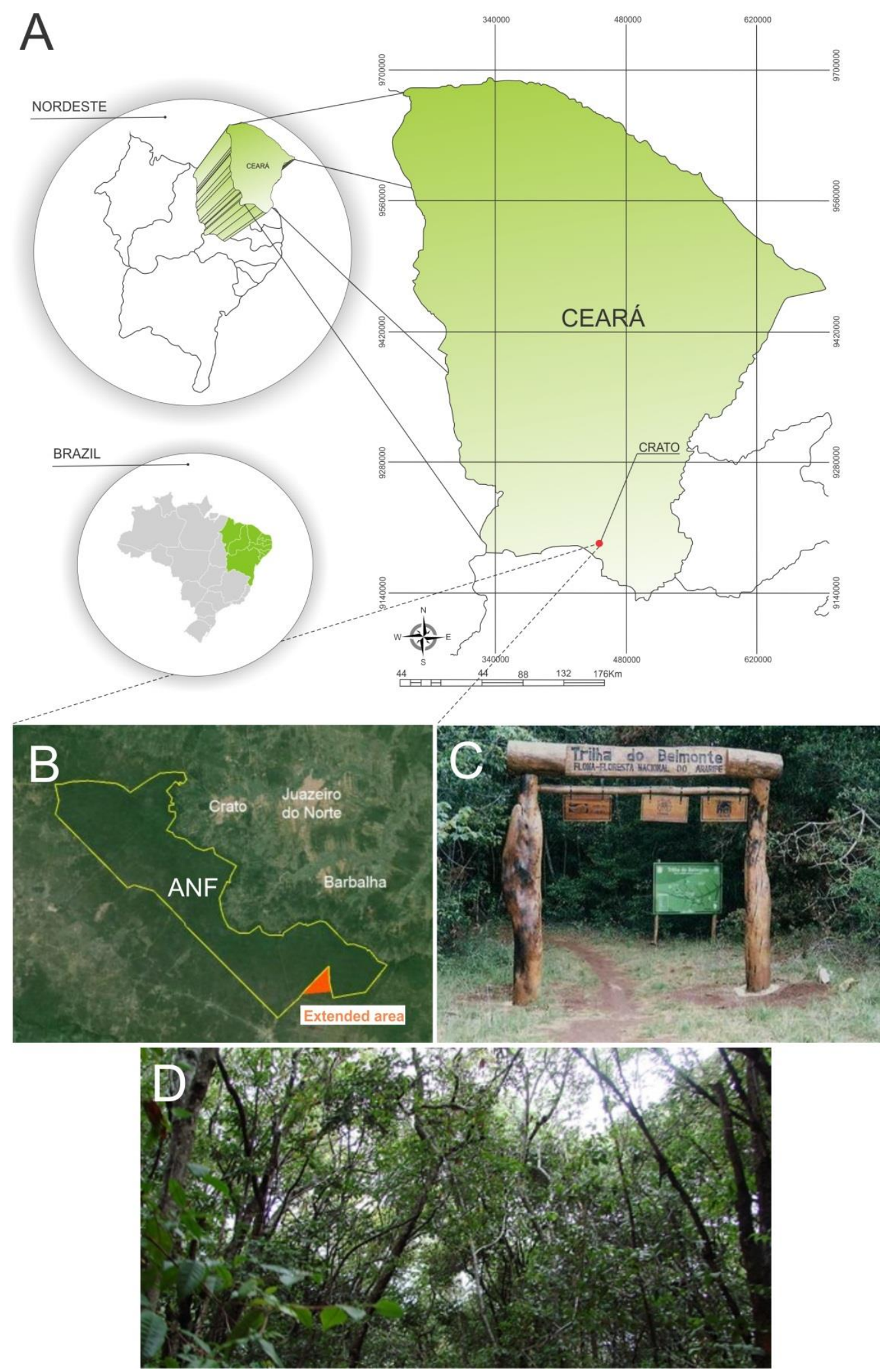

Fig. 1 A-C. A-B Location of Araripe National Forest (ANF), in Northeast Brazil. C-D ANF area and vegetation in Crato municipality, Ceará state. Pictures and Drawings: A, by Cristiano Coelho do Nascimento. B, Google Earth 2013. C-D, Archives of Araripe-PPbio Project.

in order to expand knowledge of the Agaricaceae species, this paper presents detailed descriptions and illustrations, as well as comments on the taxonomy and ecology of six Agaricaceae species from Araripe National Forest. 


\section{Materials \& Methods}

The specimens were collected during forays at the Araripe National Forest, located on the Araripe Plateau (Chapada do Araripe), in the southern tip of the Ceará state in northeastern Brazil, covering a total area of 38.626 ha. This protected area crosses the municipalities of Santana do Cariri, Crato, Jardim and Barbalha and extends from latitudes $07^{\circ} 11^{\prime} 42^{\prime \prime}$ to $07^{\circ} 28^{\prime} 38^{\prime \prime} \mathrm{S}$ and longitudes $39^{\circ} 13^{\prime} 28^{\prime \prime}$ to $39^{\circ} 36^{\prime} 33^{\prime \prime} \mathrm{W}$ (Fig.1). The ANF comprises an average annual rainfall about $1,100 \mathrm{~mm}$ and rainy season occurring between the months of January and April (IPECE 2012). In terms of physiognomic attributes, the region is an area of vegetation types associated with the wet dry tropical climate, within which the highest coverage percentage is represented by the montane rainforest (humid forest), savanna (cerrado), savanna woodland (cerradão) and carrasco, comprising transition vegetation types (Austregésilo-Filho et al 2001, IBAMA 2004).

Field collections took place in January 2011. Specimens were collected, documented and preserved using standard methods (Largent et al. 1986). The material was photographed in the field using a digital camera and extensive notes on the basidiomes were made before drying. Microscopic analysis of the material was performed using an Olympus microscope BX41 and Leica microscope DM500.

All measurements and colors reported for microscopic features were made from dried material rehydrated in $96 \%$ ethanol followed by distilled water $+1 \%$ Congo red, $3 \% \mathrm{KOH}$, or Melzer's reagent. At least 25 measurements were made of each microstructure. Spore statistics data follows the methodology proposed by Largent \& Abell-Davis (2011), slightly modified by Alves \& Nascimento (2012) and include: arithmetic means $\left(\mathrm{x}_{\mathrm{m}}\right)$ of basidiospore lengths and widths \pm standard deviation measured for $\mathrm{n}$ objects; quotient of basidiospore length by spore width (E) indicated as a range variation in $\mathrm{n}$ objects measured; the mean of E-values $(\mathrm{Q}) \pm$ standard deviations. The sample size $(n)=$ total number of basidiospores measured $(x)$ divided by the number of basidiomata studied (y), as shown in the formula $n=x / y$.

Colour-codes are adopted from the Methuen Handbook of colour (Kornerup \& Wanscher 1978). The documented material has been deposited at the Herbarium Delta (HDELTA), Department of Biology, Federal University of Piauí, Campus Parnaíba.

\section{Results and Discussion}

Agaricus stijvei de Meijer, Macrofungos notáveis das Florestas de Pinheiro-do-Paraná: 302 (2009) Fig. 2

Basidiomes dispersed, pluteoid. Pileus $42-65 \mathrm{~mm}$, at first truncately conical then expanding to plano-convex, becoming plane to slightly concave; surface grayish orange (5AB5), pale brown (7D5) at centre, dry, densely fibrillose with radiating innate fibrils, not squamulose. Context in pileus, whitish (1A1), unchanging, thin, up to $5 \mathrm{~mm}$ thick near the stipe but much thinner over the lamellae. Lamellae crowded, free, subventricose, up to $4 \mathrm{~mm}$ broad, at first pure white (1A1), becoming brown (7E4), and finally dark brown (7F5). Stipe 48-65 × 4-7.3 mm, central, cylindrical, expanding below into a basal bulb, hollow; surface entirely pure white (1A1), base quickly turning light yellow (1A2) when pressed or bruised; smooth-fibrillose, slightly striate; annulus attached to the middle part of the stipe, descending, pure white (1A1), membranous, simple, with a floccose inner edge. Spore print dark brown (7F5). Odor mild. Taste not checked.

Basidiospores 4.3-4.8 $\times 3-3.7 \mu \mathrm{m}\left(\mathrm{x}_{\mathrm{m}}=4.55 \pm 0.9 \times 3.35 \pm 0.4 \mu \mathrm{m} ; \mathrm{E}=1.30-1.43 ; \mathrm{Q}=\right.$ $1.37 \pm 0.192 ; \mathrm{n}=25 / 2$ ), broadly ellipsoid, smooth, wall $0.4 \mu \mathrm{m}$ thick, without germ pore and without apical thickening, brown. Basidia 19-25 $\times 6-8.5 \mu \mathrm{m}$ clavate, bearing four sterigmata. Lamella-edge sterile, with crowded cheilocystidia. Cheilocystidia 30-50.2 × 7-13 $\mu \mathrm{m}$, always catenate, slightly clavate, hyaline, thin-walled. Pleurocystidia absent. Hymenophoral trama composed of, hyaline, thin-walled hyphae, 3.5-14.5 $\mu \mathrm{m}$ broad, the thinner ones strictly cylindrical, broader ones up to $90 \mu \mathrm{m}$ in length and attenuated at the septa. Pileipellis consisting of cylindrical, regularly transverse septate, smooth, thin-walled hyphae, 4.3-8 $\mu \mathrm{m}$ broad, with intracellular granulose brownish yellow pigment, slightly constricted at the septa. Clamp-connexions absent. 

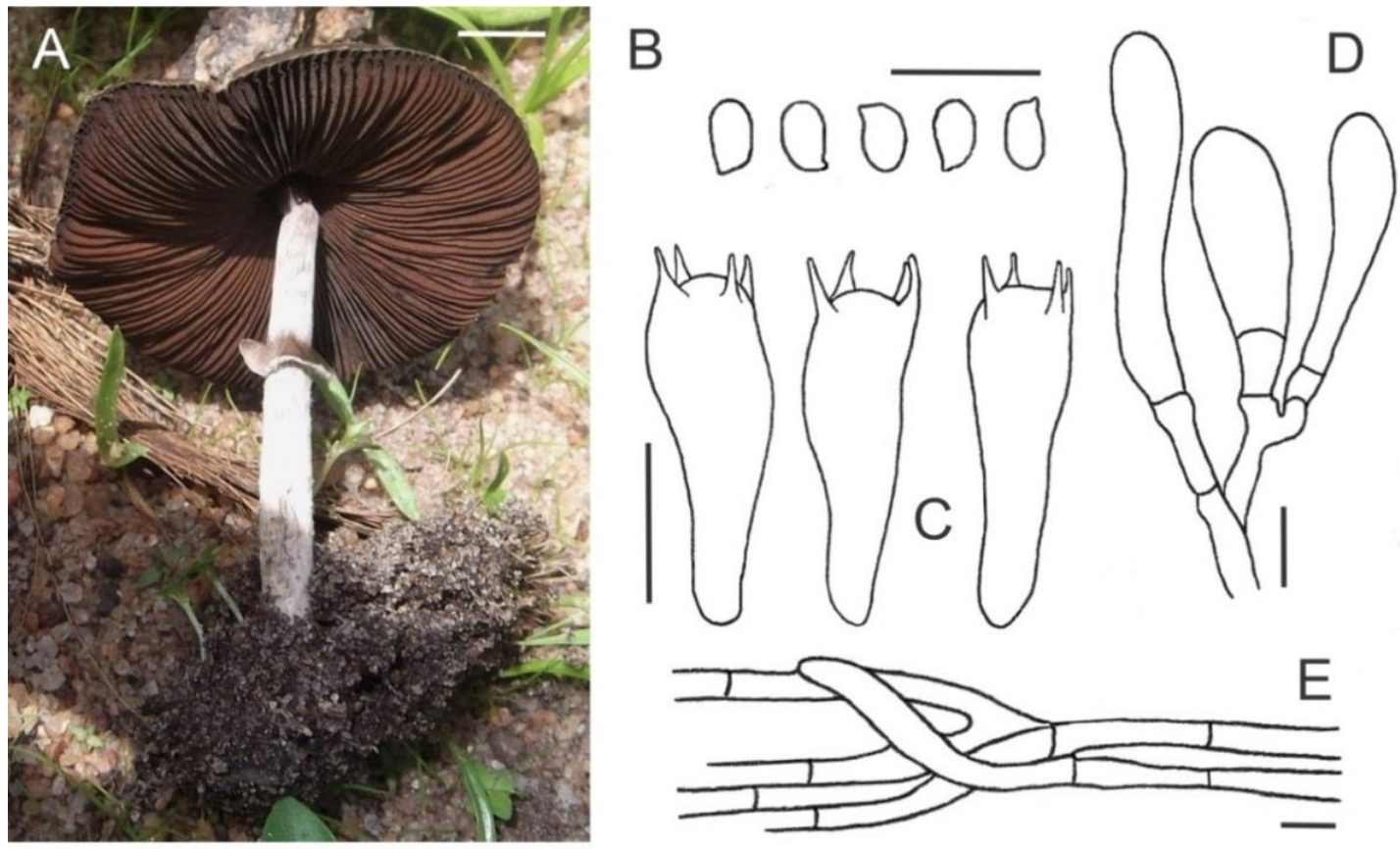

Fig. 2 A-E - Agaricus stijvei. A, Basidiome with annulus evident. B, Basidiospores. C, Basidia. D, Cheilocystidia. E, Pileipellis Bars: $10 \mu \mathrm{m}$. Photo: Maria Helena Alves. Drawings: Cristiano Coelho do Nascimento.

Known distribution - Brazil: Paraná (Maijer 2008) and Ceará (new record).

Material examined - Brazil, Ceará State, Santana do Cariri, Araripe National Forest, growing solitary on soil, 26 Jan 2011, M.H. Alves \& C.C Nascimento, 029/11 (HDELTA).

Notes - Our collection of Agaricus stijvei from ANF looks strongly similar to the holotype description by Meijer (2008) from Paraná; however slightly smaller basidiospores (4-4.5 × 3-3.5 $\mu \mathrm{m})$ and cheilocystidia $(8-30 \times 6-9 \mu \mathrm{m})$ are observed in the type protologue.

According to Meijer (2008), this species of subgen. Agaricus seems to be best placed in section Xanthodermatei Singer, on account of the quickly yellowing stipe surface, membranous annulus and poorly developed general veil. It is somewhat aberrant, nonetheless, because the inner edge of the annulus is smooth, instead of floccose-scaly as in most species of the section. Our collection from ANF clearly presents an annulus with a floccose inner edge, suggesting this might be a variable character.

Agaricus endoxanthus Berk. \& Broome (sect. Xanthodermatei), from Trinidad and Lesser Antilles, is remarkably similar to A. stijvei in its densely fibrillose pileus surface, whitish to chocolate brown hymenophore, stipe base quickly discolouring yellow on bruising, and pileal surface consisting of cylindrical, regularly transverse septate, smooth, thin-walled hyphae. However, A endoxanthus differs by the less bulbous stipe base, longer basidiospores [5-6× 3$\left.3.5 \mu \mathrm{m}\left(\mathrm{x}_{\mathrm{m}}=5.3 \pm 0.32 \times 3.2 \pm 0.18 \mu \mathrm{m} ; \mathrm{Q}=1.64\right)\right]$, and shorter cheilocystidia $(14-18 \times 8-10 \mu \mathrm{m})$ (Pegler 1983).

Agaricus stijvei was described by Meijer (2008) from Paraná and now it is a first record from the Northeast Brazil.

Chlorophyllum hortense (Murrill) Vellinga, Mycotaxon, 83: 416 (2002)

Fig. 3

Basidiomes medium to large in size, fleshy, lepiotoid. Pileus $45-78 \mathrm{~mm}$ broad, at first ovoid to conic-campanulate then expanding to plano-convex with a distinct umbo; surface whitish (1A1) with a yellowish umbo (3A3, 4A3, 4A4), dry, surface breaking up into flat, appressed, irregularly shaped scales, more densely packed toward disk, scattered and detersile toward the margin, radially oriented; scales whitish (1A1) to cream color (4A2) on whitish (1A1) background; margin thin, 

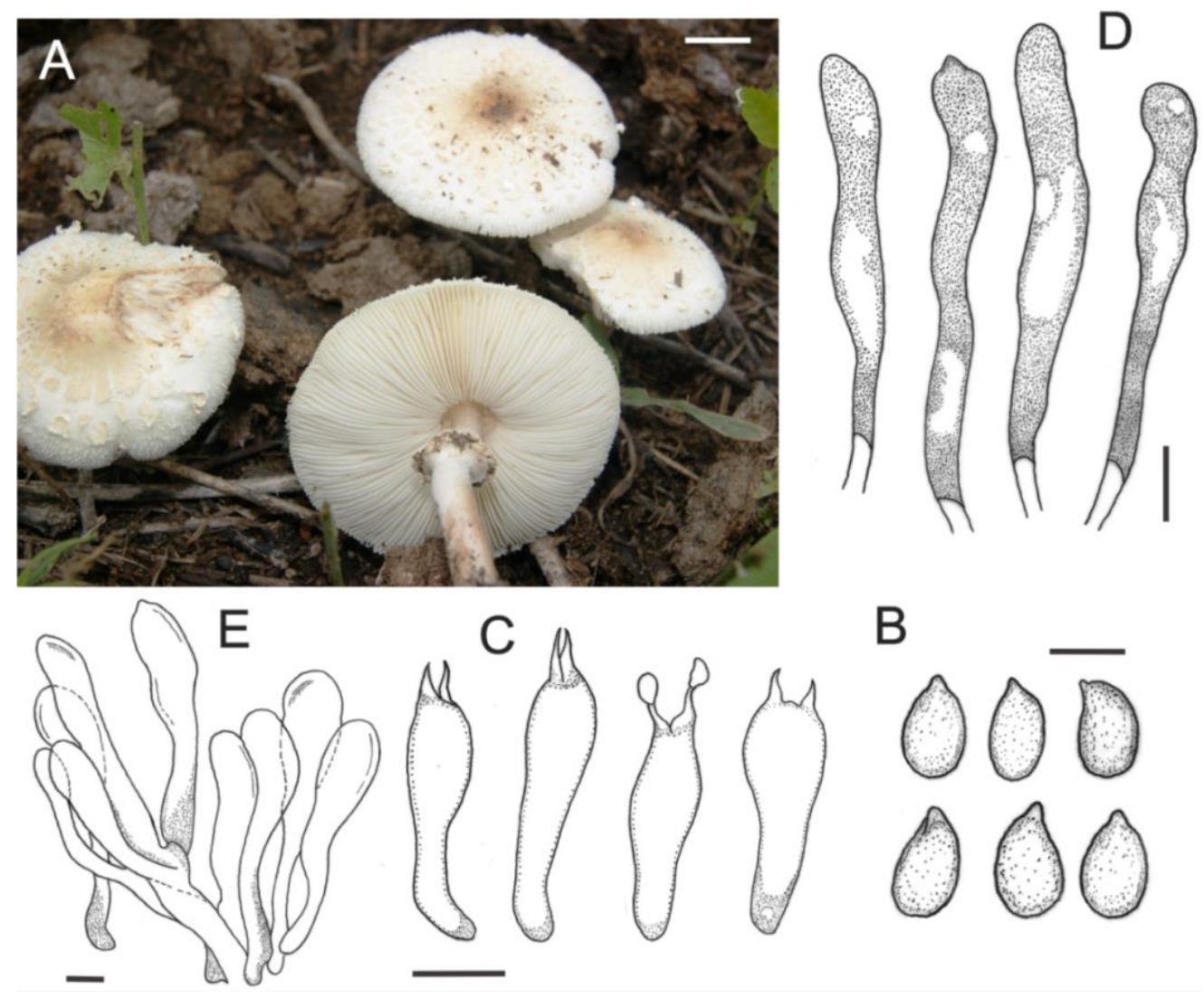

Fig. 3 - A-E - Chlorophyllum hortense. A, Basidiomes. B, Basidiospores. C, Basidia. D, Cheilocystidia. E, Trichodermial elements Bars: $10 \mu \mathrm{m}$. Photo: Maria Helena Alves. Drawings: Cristiano Coelho do Nascimento.

substriate to striate, fringed. Context in pileus, thin, about $4.5 \mathrm{~mm}$ at the disk, whitish (1A1), becoming somewhat vinaceous red on bruising or exposure, consisting of hyaline, thin-walled, inflating hyphae, 3.5-22.5 $\mu \mathrm{m}$ diam., septa hardly ever bearing clamp-connexions. Lamellae free, subventricose, crowded to very crowded, whitish, concolorous edge, up to $5.5 \mathrm{~mm}$ broad, with lamellulae of several lengths. Stipe 45-80 × 4-6 mm, central, cylindrical, expanding below into a basal bulb, fistulose; surface whitish (1A1), smooth, glabrous, with a strong reddening (7B6) reaction when pressed, cut or bruised; annulus witish (1A1), superior, persistent, membranous, double. Spore print white (1A1). Odor and taste not checked.

Basidiospores 9.5-12 × 7-8.3 $\mu \mathrm{m}\left(\mathrm{x}_{\mathrm{m}}=10.75 \pm 1.2 \times 7.65 \pm 0.7 \mu \mathrm{m} ; \mathrm{E}=1.36-1.45 ; \mathrm{Q}=\right.$ $1.40 \pm 0.242 ; \mathrm{n}=25 / 4$ ), ellipsoid to ovoid, hyaline, dextrinoid, without a germ pore, thick-walled (about $0.6 \mu \mathrm{m}$ ), metachromatic in Cresyl blue. Basidia 20-32 × 6-10.5 $\mu \mathrm{m}$, clavate, hyaline, 2spored basidia, sterigmata up to $6.9 \mu \mathrm{m}$ long. Lamella-edge sterile, with abundant cheilocystidia. Cheilocystidia 39-60.7 $\times 5-8.5$, cylindrical to narrowly clavate, rare mucronate, slightly sinuous, sometimes constricted, hyaline, thin-walled. Pleurocystidia absent. Hymenophoral trama regular, hyaline, consisting of thin-walled hyphae, 3-8 $\mu \mathrm{m}$ diam., including some scattered oleiferous hyphae with golden yellow content. Subhymenial layer well developed, 9-15.4 $\mu \mathrm{m}$ wide. Pileipellis a subhymeniform layer of long-clavate to cylindro-clavate elements, sometimes mucronate, terminal cells $60-115.5 \times 9.8-16.5 \mu \mathrm{m}$, thin-walled.

Known distribution - has a wide (sub-) tropical distribution (Pegler 1983, Aberdeen 1992, Akers \& Sundberg 1997, Vellinga 2003).

Material examined - Brazil, Ceará State, Santana do Cariri, Araripe National Forest, growing scattered on dung, compost soil, 26 Jan 2011, M.H. Alves and C.C Nascimento, 032/11 (HDELTA). 
Notes - Chlorophyllum hortense is characterized by medium to large-sized, whitish basidiomes with whitish squames on the pileus and a yellowish umbo, a strong reddening reaction when the stipe is pressed, cut or bruised, a double annulus, spores without a germ pore, 2-spored basidia, cylindrical cheilocystidia and rare clamp-connexions (Vellinga 2003).

Molecular work by Vellinga et al. (2003) has shown that the species belongs to the same clade as Chlorophyllum molybdites and C. rachodes and a position within Leucoagaricus was ruled out.

Chlorophyllum hortense was previously reported in Brazil by Sobestiansky (2005) from Rio Grande do Sul State. The present collection is the first record from the Northeast Brazil, occurring on dung, compost enriched soil.

Cystolepiota seminuda (Lash) Bon Documents Mycologiques 6(24): 43 (1976)

Fig. 4

Basidiomes small in size, slender, lepiotoid. Pileus $19-25 \mathrm{~mm}$ broad, conic-campanulate when young, then plano-convex to applanate or with a poorly defined umbo; surface whitepowdered (1A1), becoming pale pink (7A2) when pressed, covered with small, granulose, whitish to slightly cream (4A2) squamules, and a pale clay disk; margin with hanging veil remnants. Context in pileus thin, whitish (1A1), of loosely woven, thin-walled, hyaline hyphae, 2-5 $\mu \mathrm{m}$ diam., with clamp-connexions. Lamellae free, crowded to very crowded,whitish (1A1) to pale pinkish (7A2), with lamellulae of several lengths, edges smooth. Stipe 25-45 $\times 2-4 \mathrm{~mm}$, central, cylindrical, hollow, equal with a bulbous base; surface whitish (1A1) to slightly vinaceous, powdery mealy; annulus snow-white (1A1), evanescent, attached to the upper third of the stipe. Spore print white (1A1). Odor and taste not checked.

Basidiospores 3.5-5 × 2.7-3.4 $\mu \mathrm{m}\left(\mathrm{x}_{\mathrm{m}}=4.25 \pm 0.47 \times 3 \pm 0.56 \mu \mathrm{m} ; \mathrm{E}=1.30-1.47 ; \mathrm{Q}=\right.$ $1.38 \pm 0.223 ; \mathrm{n}=25 / 3$ ), broadly ellipsoid, sometimes slightly cylindric, hyaline, smooth, lacking a germ-pore, non-dextrinoid. Basidia 19-28 × 8-13.5 $\mu \mathrm{m}$, hyaline, clavate, bearing four sterigmata, up to $3 \mu \mathrm{m}$ long. Lamella-edge with scattered cheilocystidia. Cheilocystidia rare, difficult to observe, (14-)18-28 × 5-9 $\mu \mathrm{m}$, clavate, hyaline, thin-walled. Pleurocystidia absent. Pileipellis a disrupted epithelium of hyaline, smooth, thin-walled, subglobose to globose sphaerocysts, 10-28 $\mu \mathrm{m}$ diam., with a loose or catenulate arrangement.

Known distribution - South America (Guzmán \& Guzmán-Davalos 1992, Albuquerque et al. 2010), Asia (Chou 2010, Asef \& Muradov 2012), Europe (Bon 1981, Candusso \& Lanzoni 1990, Breitenbach \& Kränzlin 1995).

Material examined - Brazil, Ceará State, Crato, Araripe National Forest, growing in pairs on humous soil, 25 Jan 2011, collectors: M.H. Alves and C.C Nascimento, 020/11 (HDELTA).

Notes - This small mushroom was mainly distinguished by the white pileus, becoming pale pink when pressed, mealy coating of fruit body, non-dextrinoid basidiospores, and the pileipellis composed of globose cells. These features are diagnostic of the material herein recognized as Cystolepiota seminuda, and match the description present in Candusso \& Lanzoni (1990), Albuquerque et al. (2010), Chou (2010) and Asef \& Muradov (2012) for this especies.

This delicate, white-powdered mushroom prefers neutral to base rich or calcium rich soils (Kreisel 1987), and occurs sometimes on ruderal and other substitute places (gardens, parks) rather on non-fertilized soils (Ludwig 2001). Our collection was recorded growing on black humus enriched ground at Araripe National Forest, Crato, confirming its preference for enriched soils.

The type collection of Lepiota rufipes Morgan was studied by Vellinga (2010), and L. rufipes was placed in synonymy with $C$. seminuda. On type study of $L$. rufipes in the ISC herbarium, Vellinga (2010) documented macro- and micromorphological features congruent with our findings for present collection, although she emphasized that cheilocystidia were not observed. Indeed C. seminuda is commonly described not possessing cystidia (Candusso \& Lanzoni 1990, Chou 2010, Asef \& Muradov 2012); however, narrowly clavate cheilocystidia are mentioned by Vellinga \& Huijser (1999) and Albuquerque et al. (2010). The fresh analysis of our material revealed inconspicuous cheilocystidia, mostly narrowly clavate, which were not observed in the dried material after rehydration. 

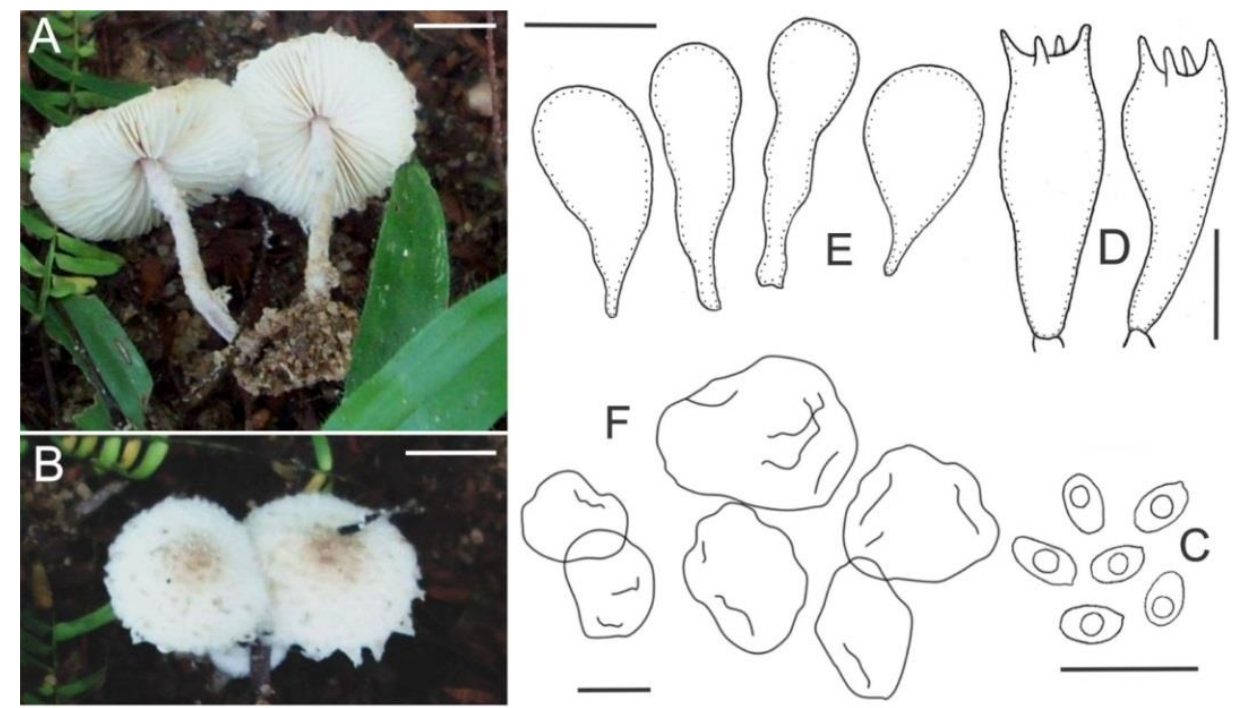

Fig. 4 A-F - Cystolepiota seminuda. A-B Basidiomes. C Basidiospores. D Basidia. E Cheilocystidia. F Elements of pileus covering. Bars: $10 \mu \mathrm{m}$. Photos: Maria Helena Alves. Drawings: Cristiano Coelho do Nascimento.

Cystolepiota seminuda was previously reported in Brazil from the States of Rio Grande do Sul (Rick, 1937; Putzke, 1994) and Rio de Janeiro (Albuquerque et al. 2010). The present collection is the first record from the Northeast Brazil.

Lepiota plumbicolor (Berk. \& Broome) Sacc., Sylloge Fungorum, 4: 63 (1887)

Fig. 5

Basidiomes small in size, lepiotoid. Pileus $25-30 \mathrm{~mm}$ broad, conic-campanulate when young, then expanding to plano-convex, slightly raised at the centre, sometimes with a distinct central umbo; surface greyish brown (7D2) to violet brown (11E5) at the centre, yellowish white (4A2) elsewhere, scaly; squamules, repent, light brown (6D5) which are concentrated at the disk but sparse at the margin; margin straight, entire, sometimes splitting at maturity. Context in pileus greyish white (1A1) to slightly yellowish (1A2), up to $2.5 \mathrm{~mm}$ thick at the disk but much thinner over the lamellae. Lamellae free, subcrowded, ventricose, yellowish white (2A2), with lamellulae of several lengths, edge concolorous, pruinose. Stipe $28-37 \times 2-3.2 \mathrm{~mm}$, central, cylindrical, equal or expanding slightly at the base, with a subbulbous base, hollow; surface concolorous with the pileus, pruinose fibrillose; annulus whitish, fragile, attached to the upper third of the stipe, soon evanescent. Spore print white (1A1). Odor and taste not checked.

Basidiospores 6.8-9.8 $\times 3.5-5 \mu \mathrm{m}\left(\mathrm{x}_{\mathrm{m}}=8.3 \pm 0.5 \times 4.25 \pm 0.4 \mu \mathrm{m} ; \mathrm{E}=1.94-1.96 ; \mathrm{Q}=1.95\right.$ $\pm 0.192 ; n=25 / 2)$, elongate ellipsoid, hyaline, thin-walled, dextrinoid. Basidia (15- 17.5-28.5 $\times 5-$ $8 \mu \mathrm{m}$, clavate, sometimes clavate-cylindric, hyaline, thin walled, bearing four sterigmata up to 3 $\mu \mathrm{m}$. Lamella-edge sterile, with abundant cheilocystidia. Cheilocystidia 25-39.5 $\times 5-8 \mu \mathrm{m}$, crowded, clavate-cylindric, pedicellate with clamp-connexions, hyaline, thin-walled. Pleurocystidia absent. Hymenophoral trama parallel, hyaline. Pileipellis a trichodermial palisade formed of septate, elongate clavate to short clavate terminal elements, in size, with rounded apices, often with clampconnexions at the septa, containing a brown vacuolar pigment and a slightly thickened pale brown wall.

Known distribution - South America (Rick, 1961), Asia (Pegler 1972, 1986, Kumari et al. 2012, Farook et al. 2013).

Material examined - Brazil, Ceará State, Crato, Araripe National Forest, growing solitary on soil, 24 Jan 2011, collectors: M.H. Alves and C.C Nascimento, 010/11 (HDELTA).

Notes - The above collection can be recognized by the following combination of characters: miniature stature, pileus greyish to purplish at the centre, yellowish white elsewhere, dextrinoid basidiospores, clamped cheilocystidia and pileipellis a trichodermial palisade formed of septate, elongate clavate to short clavate terminal elements. 

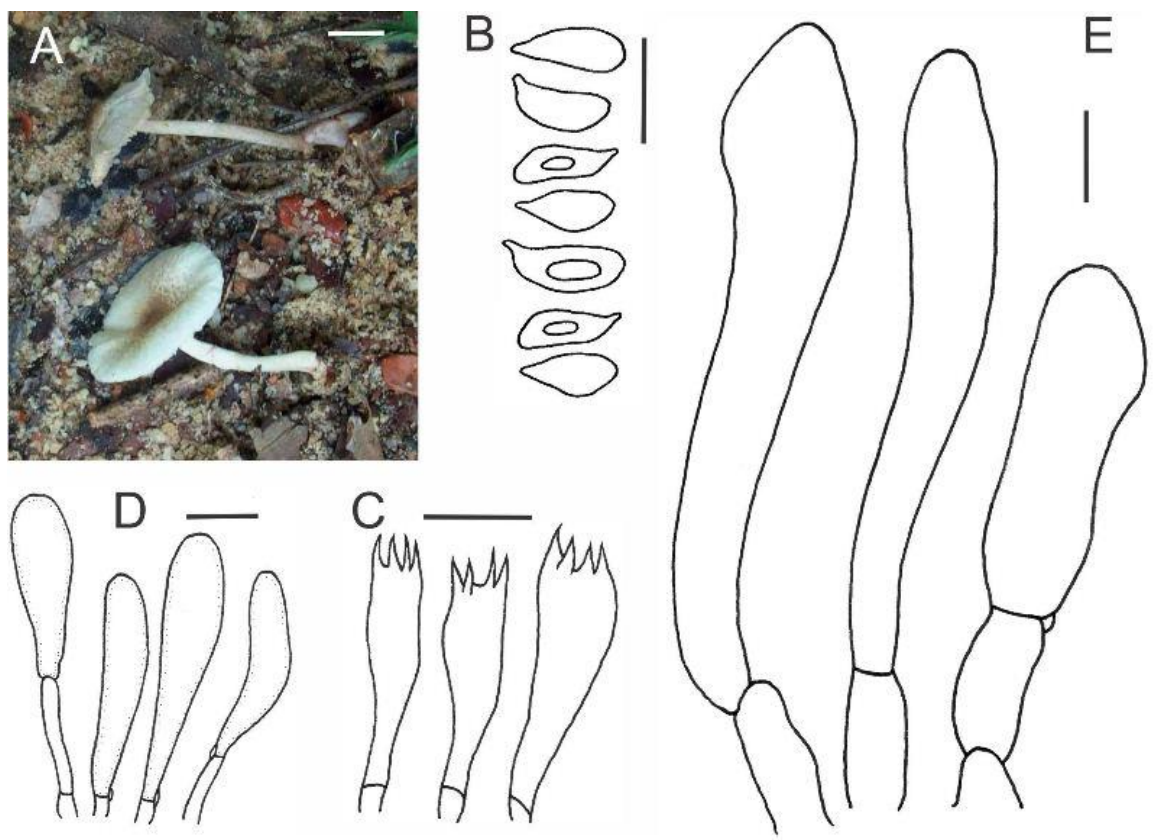

Fig. 5 A-E - Lepiota plumbicolor. A, Basidiomes. B, Basidiospores. C, Basidia. D, Cheilocystidia. E, Pileipellis elements. Bars: $10 \mu \mathrm{m}$. Photo: Maria Helena Alves. Drawings: Cristiano Coelho do Nascimento.

This species was previously placed in the sect. Anomalae Locq., owing to the failure to observe clamp-connexions on the context hyphae by Pegler (1972). A re-examination by Pegler (1986) has revealed conspicuous clamp-connexions on the hyphae which form the stipe squamules so that species was more correctly placed on sect. Ovisporae (J. Lange) Kuehner. In our collection the clamp-connexions were observed only on the pileipellis terminal elements and in the cheilocystidia base, confirming the placement of Lepiota plumbicolor in the sect. Ovisporae.

The present collection is the first record for the species from Brazilian Northeast. It was reported before from the Rio Grande do Sul state (Rick 1961).

Leucocoprinus birnbaumii (Corda) Singer, Sydowia, 15 (1-6): 67 (1962)

Fig. 6

Basidiomes small to medium in size, lepiotoid. Pileus $15-65 \mathrm{~mm}$ broad, at first narrowly conical, then becoming plano-convex to applanate, with a truncated apex then expanding but retaining a more or less distinct umbo; surface mostly light yellow (1A5) to greyish yellow (1B3), sometimes deep yellowish (2A8), floccose squamulose; squamules repent, loose, concolorous, concentrated at the disk but sparse at the margin; margin thin, slightly plicate-striate until the half-way or less to the disk. Context in pileus fleshy, thin, concolorous with the pileus, unchanging, consisting of hyaline, inflated hyphae, 3.3-12.2 $\mu \mathrm{m}$ diam., with a slightly thickened wall. Lamellae free, subcrowded to crowded, concolorous with the pileus surface, thin, with lamellulae. Stipe 45-85 $\times 4-7 \mathrm{~mm}$, central, hollow, cylindrical, slightly expanding toward the swollen base (about $15 \mathrm{~mm}$ ); surface concolorous with the pileus, often sparsely floccose towards base; annulus superior, membranous, ascending, evanescent, concolorous with the stipe. Spore print white (1A1). Odor mild. Taste not checked.

Basidiospores (7.3-) 8-10.5(-11.5) $\times 5-7.5(-8.0) \mu \mathrm{m}\left(\mathrm{x}_{\mathrm{m}}=9.25 \pm 1.2 \times 6.25 \pm 0.55 \mu \mathrm{m} ; \mathrm{E}=\right.$ 1.4-1.6; $\mathrm{Q}=1.5 \pm 0.242 ; \mathrm{n}=25 / 3)$, ovoid to ellipsoid, truncated at the apex, with a distinct germpore, hyaline, thick-walled, dextrinoid, metachromatic with Cresyl blue. Basidia 25-38.5 × 7.5-11(13) $\mu \mathrm{m}$, clavate, hyaline, thin walled, bearing four sterigmata up to $4 \mu \mathrm{m}$. Lamella-edge sterile, with abundant cheilocystidia. Cheilocystidia 25-39.5 $\times 5-8 \mu \mathrm{m}$, with various formats (strongly clavate, ventricose, piriform, lageniform), sometimes with a mucronate apex hyaline, thin-walled. Pleurocystidia absent. Hymenophoral trama regular, consisting of thin-walled, hyaline hyphae, 3.5$11.5 \mu \mathrm{m}$ diam. Pileipellis an epicutis of interwoven, branched chains of hyphal elements, 30-120 $\times$ 7-12 $\mu \mathrm{m}$, soon becoming disrupted, hyaline, thin-walled. 

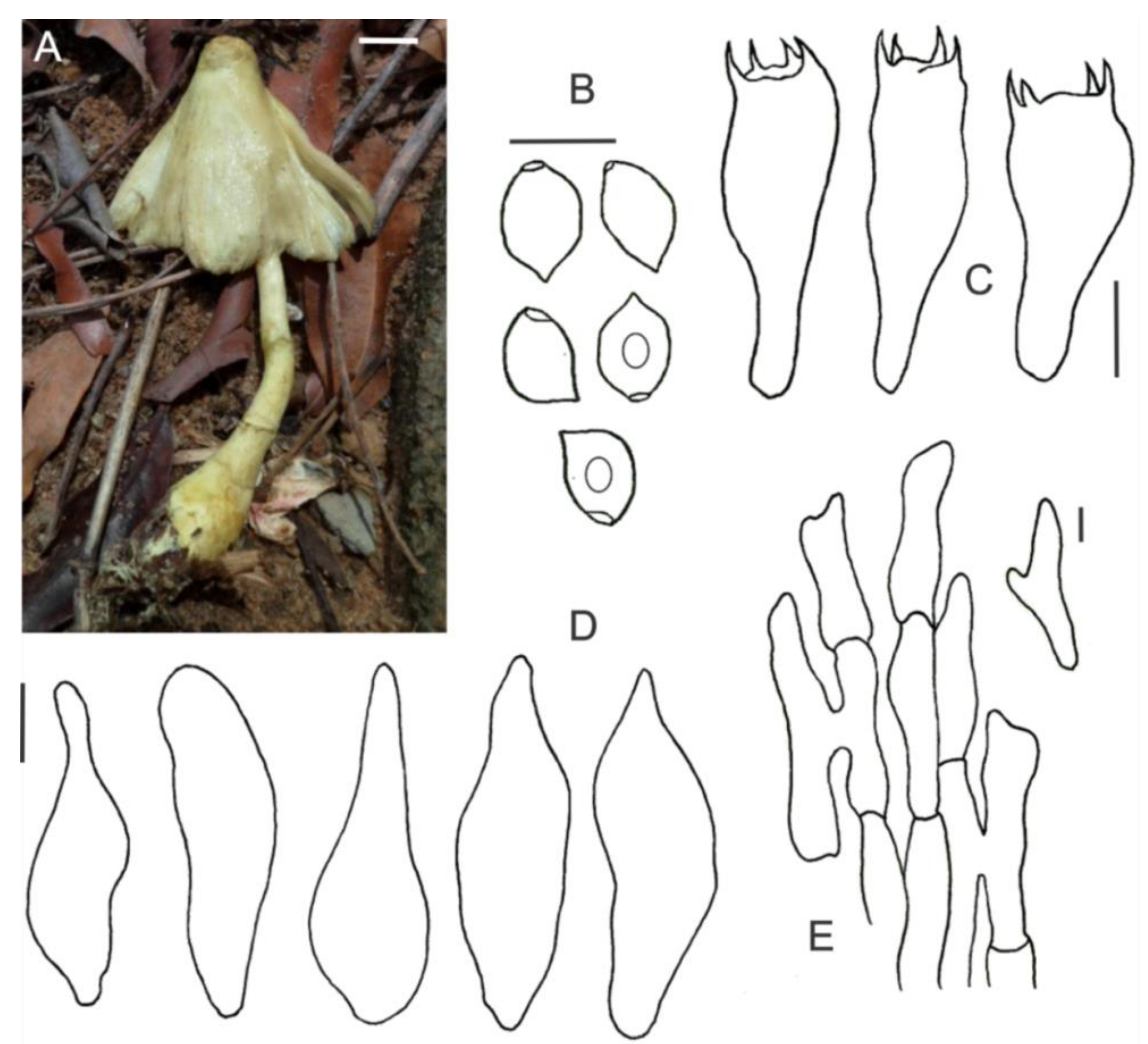

Fig. 6 A-E - Leucocoprinus birnbaumii. A, Basidiome. B, Basidiospores. C, Basidia. D, Cheilocystidia. E, Pileus covering hyphae. Bars: $10 \mu \mathrm{m}$. Photo: Maria Helena Alves. Drawings: Cristiano Coelho do Nascimento.

Known distribution - Europe (Bon 1981, Breitenbach \& Kränzlin 1995, Candusso \& Lanzoni 1990, Vellinga 2001). Asia (Pegler 1972, 1986, Wasser 1993, Pushpa \& Purushothama 2011), Africa (Heinemann 1977, Pegler 1977). Americas (Dennis 1970, Guzmán-Dávalos \& Guzmán 1982, Raithelhuber 1987, Pegler 1983, 1997, Meijer 2001, 2006, Wright \& Albertó 2002, Albuquerque et al. 2006, Rother \& Silveira 2008, 2009).

Material examined - Brazil, Ceará State, Barbalha, Araripe National Forest, growing solitary on soil, 26 Jan 2011, collectors: M.H. Alves and C.C Nascimento, 040/11 (HDELTA).

Notes - Leucocoprinus birnbaumii is a typical species of Leucocoprinus Pat. (Tribe Leucocoprineae Singer) and is a common and conspicuous agaric throughout the tropical and subtropical areas of the world (Pegler 1986, Candusso \& Lanzoni 1990, Vellinga 2001). This mushroom is characterized by its light yellow to greyish yellow pileus, white spore print, spores metachromatic, dextrinoid, thick-walled, truncated with distinct germ-pore and presence of cheilocystidia. Leucocoprinus sulphurellus Pegler, a yellowish agaric known from Caribbean area, differs by smaller basidiospores and gills that bruise bright blue-green (Pegler 1983). The studied specimens are the first record for the species from the State of Ceará Brazil.

Leucocoprinus fragilissimus (Berk. \& M.A. Curtis) Pat., Essai Tax. Hyménomyc. (Lons-leSaunier): 171 (1900)

Fig. 7

Basidiomes small in size, extremely fragile. Pileus $20-40 \mathrm{~mm}$ broad, membranous, at first narrowly conical, then expanding to applanate and finally plano-concave to depressed in mature specimens; surface dry, whitish (1A1) or somewhat yellowish white (1A2), almost translucent, with a yellowish disk (4C4), plicate striate almost to the disk, covered by minute, loose granulosofurfuraceous squamules which are sometimes removed by weathering. Contex in pileus very thin. Lamellae free, membranous, remote, narrow, at first white (1A1) becoming yellowish white (1A2; 1A3) in some old specimens, subcrowded to crowded with few lamellulae. Stipe $45-90 \times 2-3 \mathrm{~mm}$, central, cylindric, hollow, glabrous, silky-striate, sometimes slightly enlarged toward the apex; 

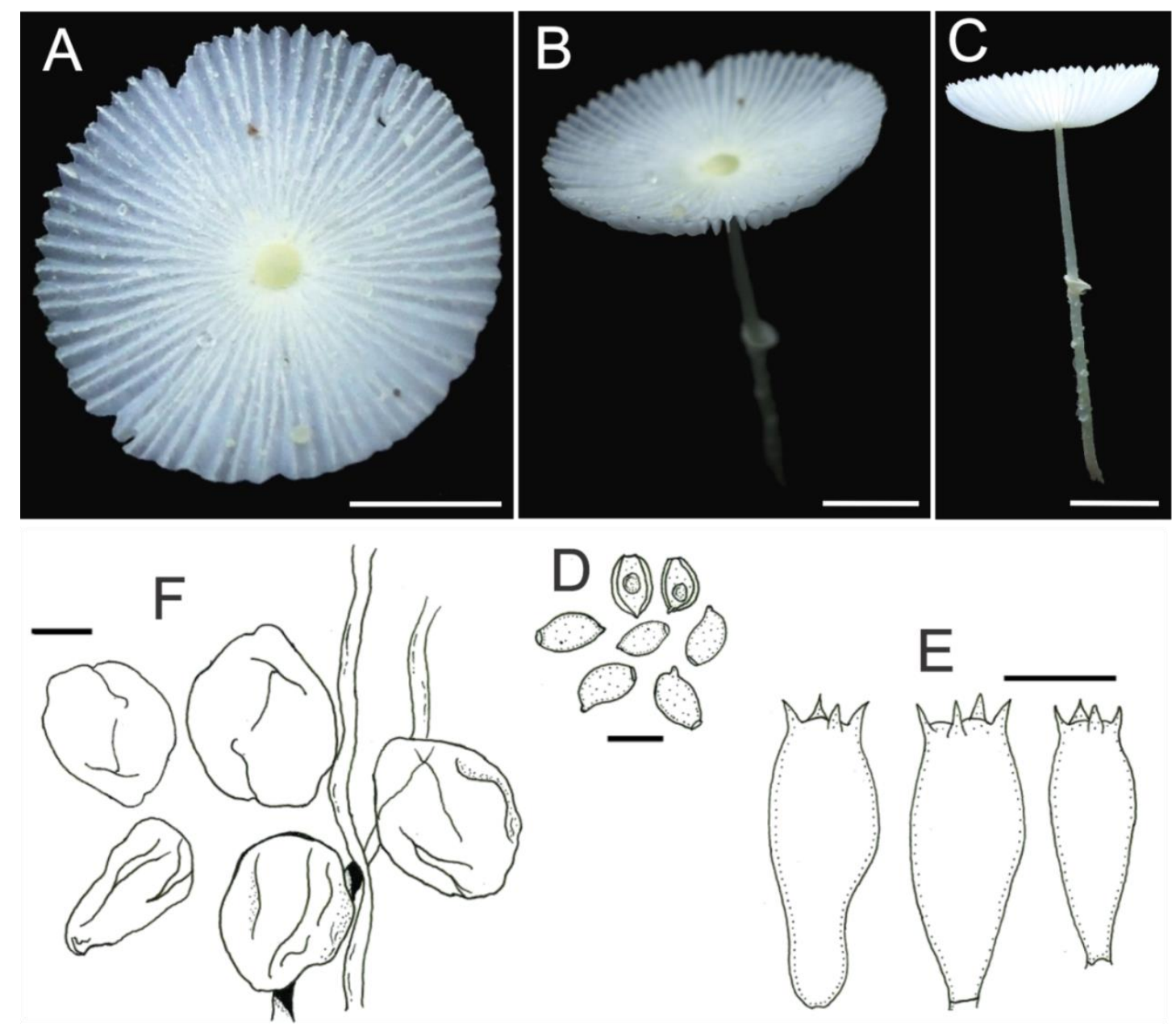

Fig. 7 A-E - Leucocoprinus fragilissimus. A-C, Basidiomes. D, Basidiospores. E, Basidia. F, Elements of the pileipellis. - Bars: $10 \mu \mathrm{m}$. Photos: Maria Helena Alves. Drawings: Cristiano Coelho do Nascimento.

surface white (1A1) or yellowish (1A2) with floccose squamules below the middle zone of the stipe. Annulus present, extremely fragile and evanescent, whitish (1A1) and attached to the middle part of the stipe. Spore print not checked. Odor distinct but unidentifiable. Taste unknown.

Basidiospores (8.2-) 8.5-12 $\times(5.2-)$ 5.5-8.5 $\mu \mathrm{m}\left(\mathrm{x}_{\mathrm{m}}=10.3 \pm 1.1 \times 7 \pm 0.6 \mu \mathrm{m} ; \mathrm{E}=1.35-\right.$ 1.62; $\mathrm{Q}=1.48 \pm 0.142 ; \mathrm{n}=25 / 3)$, broadly ellipsoid, smooth, thick-walled, hyaline, sometimes pale yellowish, truncated by a broad germ-pore, dextrinoid, metachromatic. Basidia (18-) 20-26 × 7-12 $\mu \mathrm{m}$, clavate, hyaline, thin walled, bearing four sterigmata up to $3 \mu \mathrm{m}$. Cheilocystidia and Pleurocystidia absent. Pileipellis an epicutis of irregular, thin-walled, hyaline hyphae, 3-6 $\mu \mathrm{m}$ diam., mixed with loose, hyaline sphaerocysts, 13.5-32.5 (-36) $\mu \mathrm{m}$ diam. All hyphae lack clampconnexions.

Known distribution - Africa (Heinemann 1977), America (Morgan 1907, Theissen 1912, Rick 1961, Reid et al. 1981, Smith \& Weber 1982, Pegler 1983, 1997, Capelari \& Maziero 1988, Kimbrough 2000, Franco-Molano et al. 2000, Halling \& Mueller 2005, Albuquerque et al. 2006, Meijer 2006, 2008, Rother \& Silveira 2009), Asia (Patouillard 1892, Pegler 1972, 1986, Hongo 1986, Yang 2000, Pushpa \& Purushothama 2011), Europe (Bon 1981, Cadusso \& Lanzoni 1990, Ballero \& Contu 1991).

Material examined - Brazil, Ceará State, Barbalha, Araripe National Forest, growing solitary on soil, 26 Jan 2011, collectors: M.H. Alves and C.C Nascimento, 042/11 (HDELTA).

Notes - According Pegler (1983) this is probably a common pantropical species but rarely collected owing to the extremely delicate, almost deliquescent, consistency of the basidiome. The 
distinguishing feature of this collected specimen is its white pileus, with yellow disk, fragile, translucent, plicate, long hollow stipe, spores white, metachromatic, thick walled, dextrinoid, with a germ pore. Leucocoprinus tenellus Pegler, an extremely delicate agaric known from Caribbean, is obviously closely related to L. fragilissimus and differs by larger basidiospores and absence of any yellow pigmentation (Pegler 1983). The studied specimens are the first record for the species from the State of Ceará Brazil.

\section{Acknowledgements}

This study was partly supported by Programa Biodiversidade do Semiárido - PPBio grants from Conselho Nacional de Desenvolvimento Científico e Tecnológico - CNPq. The Universidade Federal do Piauí - UFPI for the technical support and IBAMA (Instituto Brasileiro do Meio Ambiente e dos Recursos Naturais Renováveis) which allowed the collection in the Araripe National Forest.

\section{References}

Aberdeen JEC. 1992 - 'Lepiotoid genera (Agaricales) in south-eastern Queensland'. (Aberdeen Publications: Gailes).

Akers BP, Sundberg WJ. 1997 - Leucoagaricus hortensis: some synonyms from Florida and taxonomic observations. Mycotaxon 62, 401-419.

Albuquerque MP, Pereira AB, Júnior AAC. 2010 - A família Agaricaceae Chevall. em trechos de Mata Atlântica da Reserva Biológica do Tinguá, Nova Iguaçu, Rio de Janeiro, Brasil: Gêneros Agaricus, Cystolepiota e Lepiota. Acta botânica brasílica. 24, 497-509.

Albuquerque MP, Victoria F, Pereira AB. 2006 - Ecologia e distribuição do gênero Leucocoprinus Pat. no Rio Grande do Sul, Brasil. Acta Biologica Leopondensia 28, 11-16.

Alexopoulos C J, Mims CW, Blackwell M. 1996 - Introductory mycology. 4. ed. New York: John Willey \& Sons, Inc.

Alves MH, Nascimento CC. 2012 - Entoloma virescens (Sacc.) E. Horak ex Courtec., 1986 (Agaricales: Entolomataceae): The first record for the Caatinga biome, Ceará, Brazil. Check List 8, 577-580.

Alves MH, Nascimento CC, Andrades EO, Araujo, LRC. 2012 - Fungos da APA Delta do Parnaíba, litoral piauiense. In: Anderson Guzzi. (Org.). Biodiversidade do Delta do Parnaíba - litoral piauiense. 1ed.Teresina: EDUFPI.

Asef MR, Muradov P. 2012 - Lepiotaceous fungi (Agaricaceae) in the Iranian parto f Caucasia. Turkish Journal of Botany 32, 289-294.

Austregésilo-Filho PTA, Silva JAA, Meunier IMJ, Ferreira RLC. 2001 - Fisionomias da Cobertura Vegetal da Floresta Nacional do Araripe, Estado do Ceará. Brasil Florestal 71, 13-21.

Ballero M, Contu M. 1991 - Caratteristiche e fondamenti sistematici per l'inquadramento dei generi dele Lepiotaceae Roze ex Van Overem (Basidiomycetes, Agaricales) riscontrati in Sardegna. Candollea 46, 475-483.

Batista AC. 1957 - Alguns Agaricales saprófitos de Pernambuco. Mycopathologia et Mycologia Applicata 8(2), 127-134.

Bon M. 1981 - Cle monographique des "lepiotes" d' europe (= Agaricaceae, tribus Lepiotae et Leucocoprineae). Documents Mycologiques. 11(43), 1-77.

Breitenbach J, Kränzlin F. 1995 - Fungi of Switzerland. Volume 4: Agarics (2nd Part).

Entolomataceae, Pluteaceae, Amanitaceae, Agaricaceae, Coprinaceae, Strophariaceae. Luzern, Switzerland: Verlag Mykologia.

Candusso M, Lanzoni G. 1990 - Lepiota s.1. Saronno, Italia. Libreria Editrici Gionana Bielle.

Capelari M, Maziero R. 1988 - Fungos macroscópicos do estado de Rondônia, região dos Rios Jaru e Ji-Paraná. Hoehnea 15, 28-36.

Chou WN. 2010 - Nine Species of Lepiota sensu lato (Basidiomycota) New to Taiwan. Coll. and Res. 23, 1-7. 
Dennis RWG. 1970 - Fungus Flora of Venezuela and Adjacent Countries. Kew Bulletin Additional Series 3, 1-531.

Didukh MYA, Wasser SP, Nevo E. 2003 - Medicinal value of species of the family Agaricaceae Cohn (Higher Basidiomycetes): Current stage of knowleadgeand future perspectives. International Journal of Medicinal Mushrooms 5, 133-152.

Farook VA, Khan SS, Manimohan P. 2013 - A checklist of agarics (gilled mushrooms) of Kerala State, India. Mycosphere 4(1), 97-131.

Franco-Molano AE, Aldana-Gómez R., Halling R. 2000 - Setas de Colombia (Agaricales, Boletales y otros hongos) Guía de campo. Medellín. Multimpresos.

Guzmám-Dávalos L, Guzmán G. 1982 - Contribucion al conocimiento de los Lepiotaceos (Fungi, Agaricales) de Quintana Roo. Boletín de la Sociedad Mexicana de Micologia 17, 43-54.

Guzman G, Guzman-Davalos L. 1992 - A checklist of the Lepiotaceus Fungi. Champaing, Koeltz Scientific Books.

Halling RE, Mueller GM. 2005 - Common Mushrooms of the Talamanca Mountains, Costa Rica. Memoirs of the New York Botanical Garden.

Heinemann P. 1977 - Flore Illustrée Des Champignons d'Afrique Centrale. Leucocoprinus (Agaricaceae). Bull. Jard. Bot. Nat. Belg. 5, 87-109.

Hibbett DS, Thorn RG. 2001 - Basidiomycota: Homobasidiomycetes. In: Esser K, Lemke PA. The Mycota: a comprehensive treatise on fungi as experimental systems for basic and applied research. v. 7, part. B: Systematics and Evolution., Berlin: Springer-Verlag.

Hibbett DS, Pine EM, Langer E, Langer G, Donoghue M.J. 1997 - Evolution of gilled mushrooms and puffballs inferred from ribosomal DNA sequences. Proceedings of the National Academy of Sciences 94, 12002-12006.

Hongo T. 1986 - On the Agaricaceae of Japan. Transactions of the Mycological Society of Japan 27, 99-107.

IBAMA. 2004 - Plano de Manejo da Floresta Nacional do Araripe. Brasília: Ibama. 318 p.

IPECE. Perfil básico municipal. 2012 - Electronic Database accessible at http:// ipece.ce.gov.br/publicacoes/perfil_basico/perfil-basico-municipal-2012 (accessed 20 Oct 2013).

Kimbrough JW, Alves MH, Maia LC. 1994 - Basidiomycetes saprófitos em troncos vivos e em folhedos de "sombreiro" (Clitoria fairchildianai [Benth.] Howard). Biológica Brasílica, 6, 51-56.

Kimbrough JW. 2000 - Common Florida Mushrooms. Gainesville, University of Florida - Institute of Food and Agricultural Sciences.

Kirk PM, Cannon PF, Minter DW, Stalpers JA. 2008 - Ainsworth \& Bisby's dictionary of the fungi. 10. ed. Wallingford: CAB International.

Kornerup A, Wanscher JH. 1978 - Methuen Handbook of Colour. 3. ed. London, Eyre Methuen.

Kreisel H. 1987 - Pilzflora der Deutschen Demokratischen Republik. Basidiomycetes (Gallert-Hutund Baupilze). VEB G. Fischer, Jena.

Krüger D, Binder M, Fischer M, Kreisel H. 2001 - The Lycoperdales. A molecular approach to the systematics of some gasteroid mushrooms. Mycologia 93, 947-957.

Kumari B, Atri NS, Kaur M. 2012 - Some interesting lepiotoid mushrooms from North India. Mycosphere 3(6), 949-955.

Largent DL, Johnson D, Watling R. 1986 - How to identify mushrooms to genus III: microscopic features. Eureka, Mad River Press Inc.

Largent DL, Abell-Davis SE. 2011 - Observations on Inocephalus virescens comb. nov. and Alboleptonia stylophora from northeastern Queensland. Mycotaxon 116, 231-245.

Ludwig E. 2001 - Pilzkompendium Bd. 1. IHW-Verlag. Eching.

Maia LC. 1998 - Diversidade de fungos e liquens e sucessão fúngica na Reserva Ecológica Dois Irmãos. In: Machado IC, Lopes AV, Pôrto KC. Reserva Ecológica de Dois Irmãos: Estudos em um Remanescente de Mata Atlântica em Área Urbana (Recife - Pernambuco - Brasil). Recife: Editora Universitária da UFPE. 
Maia LC, Yano-melo AM, Cavalcanti MAQ. 2002 - Diversidade de Fungos no Estado de Pernambuco. In: Tabarelli M, Silva JMC. Diagnóstico da Biodiversidade de Pernambuco. Recife: Massangana.

Meijer AAR. 2001 - Mycological work in the Brazilian state of Paraná. Nova Hedwigia 72, 105159.

Meijer AAR. 2006 - Preliminary list of the macromycetes from the Brazilian State of Paraná. Boletim do MuseuBotânico Municipal 68, 1-55.

Meijer AAR. 2008 - Macrofungos notáveis das Florestas de Pinheiro-do-Paraná. Colombo, PR: Embrapa Florestas.

Moncalvo JM, Vilgalys R, Redhead SA, Johnson JE, James TY, Aime MC, Hofstetter V, Verduin SJW, Larsson E, Baroni TJ, Thorn RG, Jacobsson S, Clémençon H, Miller JR, OK. 2002 One hundred and seventeen clades of euagarics. Molecular Phylogenetics and Evolution 23, 357-400.

Morgan AP. 1907 - North American species of Lepiota. Journal of Mycology 13, 1-18.

Patouillard N. 1892 - Champignons noveau Extra-Européens. Bulletin de la Société Mycologique de France 8, 46-50.

Pegler DN. 1972 - A revision of the genus Lepiota from Ceylon. Kew Bull 27, 155-202.

Pegler DN. 1977 - A Preliminary Agaric Flora of East Africa. Kew Bulletin Additional Series 6, 1615.

Pegler DN. 1983 - The Agaric flora of Lesser Antilles. Kew Bulletin Additional Series 9, 1-668.

Pegler DN. 1986 - Agaric Flora of Sri Lanka. London: Her Majesty’s Stationery Office.

Pegler DN. 1997 - The Agarics of São Paulo, Brazil. Kew,Royal Botanical Gardens.

Pushpa H, Purushothama KB. 2011 - Leucocoprinus Pat. (Agaricaceae, Agaricales, Basidiomycota) in Bengaluru, Karnataka State, India. World Applied Sciences Journal 14 (3), 470-475.

Putzke, J. 1994 - Lista de fungos Agaricales (Basidiomycotina, Hymenomycetes) referidos para o Brasil. Caderno de Pesquisas Série Botânica 6, 1-189.

Raithelhuber, J. 1987 - Die gattung Leucocoprinus in den ABCStaaten. Metrodiana 15, 5-17.

Redhead SA, Vilgalys R, Moncalvo JM, Johnson J, Hopple JSJR. 2001 - Coprinus Pers. and the disposition of Coprinus species sensu lato. Taxon 50, 203-241.

Reid DA, Pegler DN, Spooner BM. 1981- An annotated list of the Fungi of the Galapagos Islands. Kew Bulletin 35, 847-892.

Rick, J. 1937 - Agarici Riograndenses. Lilloa 1, 307-358.

Rick J. 1961 - Basidiomycetes Eubasidii in Rio Grande do Sul- Brasilia. 5. Iheringia, Série Botânica 8, 296-450.

Rother MS, Silveira RMB. 2008 - Família Agaricaceae (Agaricales, Basidio-mycota) no Parque Estadual de Itapuã, Viamão, Rio Grande do Sul, Brasil. Revista Brasileira de Biociências 6, 259-268.

Rother MS, Silveira RMB. 2009 - Leucocoprinus Pat. (Agaricaceae) no Parque Estadual de Itapuã, Viamão, RS, Brasil. Acta Botanica Brasilica 237, 720-728.

Singer R. 1986 -The Agaricales in modern taxonomy. $4^{\text {th }}$ ed. Königstein, Koeltz: Scientific Books.

Smith HV, Weber NS. 1982 - Selected species of Leucocoprinus from Southeastern United States. Contributions from the University of Michigan Herbarium 15, 297-309.

Sobestiansky G. 2005 - Contribution to a Macromycete Survey of the States of Rio Grande so Sul and Santa Catarina in Brazil. Brazilian Archives of Biology and Technology 48, 437-457.

Theissen F. 1912 - Hymenomycetes Riograndenses. Brotéria, Série Botânica 10, 1-24.

Vellinga EC. 2001 - Leucocoprinus. In Flora Agaricina Neerlandica: critical monographs on families of agarics and boleti occurring in the Netherlands. (Noordeloos ME, Kuyper THW, Vellinga EC, eds.). A.A. Balkema Publishers, Lisse, Abingdon, Exton, Tokyo, 5: 76-84.

Vellinga EC. 2003 - Chlorophyllum and Macrolepiota (Agaricaceae) in Australia. Australian Systematic Botany. 16, 361-370.

Vellinga EC. 2004 - Genera in the family Agaricaceae: evidence from nrITS and nrLSU sequences. 
Mycological Research 108, 354-377.

Vellinga EC. 2010 - Lepiota in California: species with a hymeniform pileus covering. Mycologia 102, 64-674.

Vellinga EC, Huijser HA. (1998) 1999 - Studies in Lepiota I. Species with a hymeniform pileus covering. Belgian Journal of Botany 131,191-210.

Vellinga EC, Kok RPJ, Bruns TD. 2003 - Phylogeny and taxonomy of Macrolepiota (Agaricaceae). Mycologia 95, 442-456.

Wartchow F, Putzke J, Cavalcanti MAQ. 2008 - Agaricaceae Fr. (Agaricales, Basidiomycota) from areas of Atlantic Forest in Pernambuco, Brazil. Acta Botanica Brasilica 22, 287-299.

Wasser SP. 1993 - Tribes Cystodermateae Sing. and Leucocoprineae Sing. of the CIS and Baltic States. Libri Botanici 9, 1-105.

Wright JE, Albertó E. 2002 - Guía de los Hongos de La Región Pampeana. I. Hongos con Laminillas. Buenos Aires, L.O.L.A.

Yang Z-L. 2000 - Type studies on agarics described by N. Patouillard (and his co-authors) from Vietnam. Mycotaxon 75, 431-476. 